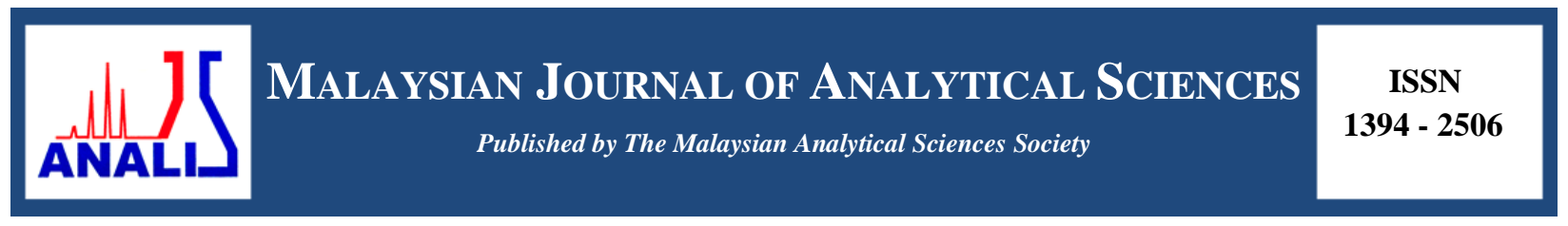

\title{
PHYTOCHEMICAL SCREENING, ANTIFUNGAL AND ANTIBACTERIAL ACTIVITIES OF Musa acuminata PLANT
}

\author{
(Saringan Fitokimia, Antikulat dan Aktiviti Antibakteria Pokok Musa acuminata)
}

\author{
Siti Suhaila Harith*, Nur Hanis Mohd Yasim, Aiza Harun, Wan Siti Atikah Wan Omar, Mohd Supi Musa \\ Faculty of Applied Sciences, \\ Universiti Teknologi MARA Pahang, 26400 Bandar Tun Abdul Razak Jengka, Pahang,Malaysia
}

*Corresponding author: ssuhaila@pahang.uitm.edu.my

Received: 4 December 2016; Accepted: 1 December 2017

\begin{abstract}
Musa acuminata plant is known for its edible fruits and the uses of its leaves as food wrapper in industries. Exploring it medicinal values will be an advantage because it can easily grow in Malaysia. The non-edible part which is the leaves of Musa acuminata 'Dwarf Cavendish' plant is analysed to determine the phytochemical constituents and antimicrobial properties. Two types of organic solvents used namely hexane and methanol. The antimicrobial properties of the extract produced were tested against Staphylococcus epidermidis and Trichophyton mentagrophytes by using disc-diffusion method. Phytochemical screening done on the sample showed that the methanolic extract contained bioactive components such as tannins, alkaloids, flavonoids, phenols, terpenoids and saponins whereas hexane extract indicated the presence of alkaloid. The methanolic extract of the leaves showed positive effects towards tested microorganisms whereas hexane extract showed vice versa. The best concentration of methanolic extract against $S$. epidermidis was $60 \mathrm{mg} / \mathrm{ml}$ and $T$. mentagrophytes were $40 \mathrm{mg} / \mathrm{ml}$ forming inhibition zone with diameter of $4.0 \mathrm{~mm}$ and $5.0 \mathrm{~mm}$, respectively. Methanolic extract against S. epidermidis is comparable to ampicillin. Meanwhile, it is remarkable that methanolic extract of M. acuminata leaves showed stronger antifungal properties as compared to nystatin. As a conclusion, the methanolic extract of the leaves of $M$. acuminata 'Dwarf Cavendish' can be nominated as potential drug due to their antifungal properties.
\end{abstract}

Keywords: Musa acuminata, banana leaves, phytochemical screening, antimicrobial properties

\begin{abstract}
Abstrak
Musa acuminata merupakan tumbuhan yang dikenali dengan buah yang boleh dimakan dan kegunaan daun sebagai pembungkus makanan dalam industri. Meneroka nilai perubatannya akan menjadi satu kelebihan kerana ia senang tumbuh di Malaysia. Bahagian yang tidak boleh dimakan iaitu daun tumbuhan Musa acuminata 'Dwarf Cavendish' dianalisis untuk menentukan juzuk fitokimia dan antimikrob. Dua jenis pelarut organik yang digunakan ialah heksana dan metanol. Sifat-sifat antimikrob ekstrak yang dihasilkan telah diuji terhadap Staphylococcus epidermidis dan Tricophyton mentagrophytes menggunakan kaedah cakera resapan. Penyaringan fitokimia dilakukan pada sampel menunjukkan bahawa ekstrak metanol mengandungi komponen bioaktif seperti tannin, alkaloid, flavonoid, fenol, terpenoid dan saponin manakala ekstrak heksana menunjukkan kehadiran alkaloid. Ekstrak metanol daun menunjukkan kesan positif terhadap mikroorganisma diuji manakala ekstrak heksana menunjukkan sebaliknya. Kepekatan terbaik ekstrak metanol terhadap S. epidermidis adalah $60 \mathrm{mg} / \mathrm{ml}$ dan T. mentagrophytes adalah $40 \mathrm{mg} / \mathrm{ml}$ membentuk zon perencatan dengan diameter masing-masing $4.0 \mathrm{~mm}$ dan $5.0 \mathrm{~mm}$. Ekstrak metanol terhadap S. epidermidis adalah setanding dengan ampicillin. Sementara itu, ekstrak metanol daun $M$. acuminata jelas menunjukkan ciri-ciri antikulat lebih kuat berbanding nystatin. Kesimpulannya, ekstrak metanol daun M. acuminata 'Dwarf Cavendish' boleh dicalonkan sebagai ubat yang berpotensi berdasarkan sifat antikulatnya.
\end{abstract}

Kata kunci: Musa acuminata, daun pisang, penyaringan fitokimia, sifat antimikrob 


\section{Introduction}

The uses of organic materials as the new source of drugs become more acknowledgeable day by day. According to Cowan [1], a large number of modern drugs have been isolated from natural sources such as plants. In the past decades, plants extracts are studied for their phytochemical contents such as alkaloids, flavonoids, amino acids and certain enzymes that make them valuable as medicinal source. Antimicrobial and antifungal are the properties of respective organisms to inhibit the growth of microorganisms such as bacteria, fungi or any pathogens. Usually, a plant contains chemicals that can act as an antimicrobial agent, which can protect it from fungal or bacterial infections. Plants are source of abundance bioactive secondary metabolites of wide variety such as tannins, terpenoids, saponins, alkaloids, flavonoids, and other compounds, reported to have in vitro antifungal properties [2].

Banana is the common name of the plant under genus Musa. Musa acuminata is the most widespread species and most diverse in Malaysia and Indonesia. This species is a hybrid of wild and cultivated bananas. Scientifically known as M. acuminata Colla (AAA Group) 'Dwarf Cavendish', the banana is a cultivar which descended from banana cultivar group of commercial produce, the Cavendish. Recently, this cultivar is the most important cultivar which represents approximate 50-60\% of the total banana production [3]. The top individual producing countries are India, the Philippines, China, Ecuador and Brazil [4]. These species are usually grown as houseplants and produce slightly smaller edible bananas than other Cavendish cultivars. M. acuminata 'Dwarf Cavendish' is an evergreen perennial to 3 meters tall, with oblong leaves to 1.2 meters long; drooping spikes of yellow flowers with purple bracts open sporadically through the year, followed by edible yellow fruit. The shortness of the plants makes them become more stable, resistant against wind and easy to handle. These make them ideal for plantation cultivation besides their fast growth rate. The fruits of the 'Dwarf Cavendish' plants are thin-skinned and range from about 15 to $25 \mathrm{~cm}$ in length.

Some recent studies had proven that the extract of pseudostem from $M$. acuminata plants showed the antimicrobial and antifungal activities against Klebsiella sp. and Streptococcus faecalis, by the formation of inhibition zone around the discs containing the extract [5]. The evaluation of the antifungal activity against Mycosphaerella fijiensis of extracts obtained from healthy leaves banana plants of $M$. acuminata $\mathrm{cv}$. Grand Nain showed significant activity [6]. An alcohol extract of banana peel of Musa paradisiaca L. has antimicrobial activity against Porphyromonas gingivalis and Aggregatibacter actinomycetemcomitans, which is proven through the formation of inhibition zone surround the discs containing the extract [7]. Thus, this study was aims to determine the phytochemical constituents and potential antimicrobial activity of M. acuminata 'Dwarf Cavendish' leaves.

\section{Source of microorganisms}

\section{Materials and Methods}

The bacterial culture used was the S. epidermidis and the fungal culture was T. mentagrophytes. These cultures were obtained from the culture stock of Universiti Teknologi MARA Pahang.

\section{Chemicals and media}

The list of chemicals used were methanol $(\mathrm{MeOH})$, sodium hydroxide solution $(\mathrm{NaOH})$, hydrochloric acid $(\mathrm{HCl})$, sulphuric acid $\left(\mathrm{H}_{2} \mathrm{SO}_{4}\right)$, ferric chloride solution $\left(\mathrm{FeCl}_{3}\right)$, hexane, Meyer's and Wagner's reagent, ampicillin, nystatin and ethanol. The bacteria were cultured in nutrient broth and maintained in nutrient agar at $37{ }^{\circ} \mathrm{C}$ throughout the study, where the fungi were cultured by using Tryptic Soy Broth and maintained in Potato Dextrose agar, also at 37 ${ }^{\circ} \mathrm{C}$ throughout the study.

\section{Source of plant materials}

The leaves of Musa acuminata 'Dwarf Cavendish' plant was collected from neighbourhood areas in Marang, Terengganu.

\section{Preparation of leaves extract}

The leaves were washed thoroughly and dried using an oven at $40{ }^{\circ} \mathrm{C}$ for about 3 days. The leaves then cut into small pieces and grinded using a grinder until fine powder produced. The extraction was done sequentially, in which 
the extract soaked in hexane first before the methanol, both with the ratio of 1:3. The extract soaked in the hexane before was dried and weighed again, and then soaked in 95\% methanol to produce the methanol extraction. The mixture was then filtered and evaporated until dry by using a rotary evaporator.

\section{Phytochemical test}

For qualitative phytochemical screening, standard methods as reported by Narendra et al. [8] and Tiwari et al. [9] were used. Froth test for detection of saponins, alkaline reagent test for flavonoids, Wagner's test for alkaloid, Ferric Chloride test for detections of tannins and phenols, and Salkowski test for detection of terpenoids were done. The antibacterial and antifungal activities of hexane and methanolic extract were tested using disc-diffusion method at different concentration.

\section{Results and Discussion}

The qualitative phytochemical screening showed most of the respective chemical contents presented in the leaves' methanol extract (Table 1). Methanol is an effective solvent that is used for extraction. In many studies, methanol extracts showed the greatest amount of phytochemicals which are important for medicinal purposes [10].

Table 1. Phytochemical analysis of different extracts of $M$. acuminata leaves

\begin{tabular}{lcc}
\hline \multirow{2}{*}{ Test } & \multicolumn{2}{c}{ Extraction } \\
\cline { 2 - 3 } & Hexane & Methanol \\
\hline Alkaloids & + & + \\
Saponins & - & + \\
Terpenoids & - & + \\
Tannins & - & + \\
Phenols & - & + \\
Flavonoids & - & + \\
\hline
\end{tabular}

\section{Antimicrobial assays}

The antimicrobial activities of hexane extract and methanolic extracts of the banana leaves were tested against $S$. epidermidis and T. mentagrophytes by using disc-diffusion method. The data pertaining to the antimicrobial potential extract of the leaves of Musa sp. against S. epidermidis were presented in Table 2. The diameters of growth inhibition zone were in the range maximum of $4.0 \pm 0.33 \mathrm{~mm}$ and minimum of $2.0 \pm 0.58 \mathrm{~mm}$ whereas the standard drug, ampicillin had zones of inhibition of $4.0 \pm 0.33$. The largest inhibition zone formed using $60 \mathrm{mg} / \mathrm{ml}$ and 80 $\mathrm{mg} / \mathrm{mL}$ extract, while the smallest zone was formed using $20 \mathrm{mg} / \mathrm{ml}$ extract. Figure 1 illustrates zone of inhibition for both solvent against $S$. epidermidis.

Table 2. Antimicrobial activities of hexane and methanolic extracts against S. epidermidis

\begin{tabular}{lcc}
\hline \multirow{2}{*}{$\begin{array}{l}\text { Concentration } \\
(\mathbf{m g} / \mathbf{m l})\end{array}$} & \multicolumn{2}{c}{ Average Inhibition Zone $(\mathbf{m m})$} \\
\cline { 2 - 3 } & Hexane Extract & Methanol Extract \\
\hline 20 & - & $2.0 \pm 0.58$ \\
40 & - & $3.0 \pm 0.33$ \\
60 & - & $4.0 \pm 0.33$ \\
80 & - & $4.0 \pm 0.33$ \\
100 & - & $3.0 \pm 0.33$ \\
Ampicillin & $4.0 \pm 0.33$ & $4.0 \pm 0.33$ \\
\hline
\end{tabular}

Data given are mean \pm standard deviation 

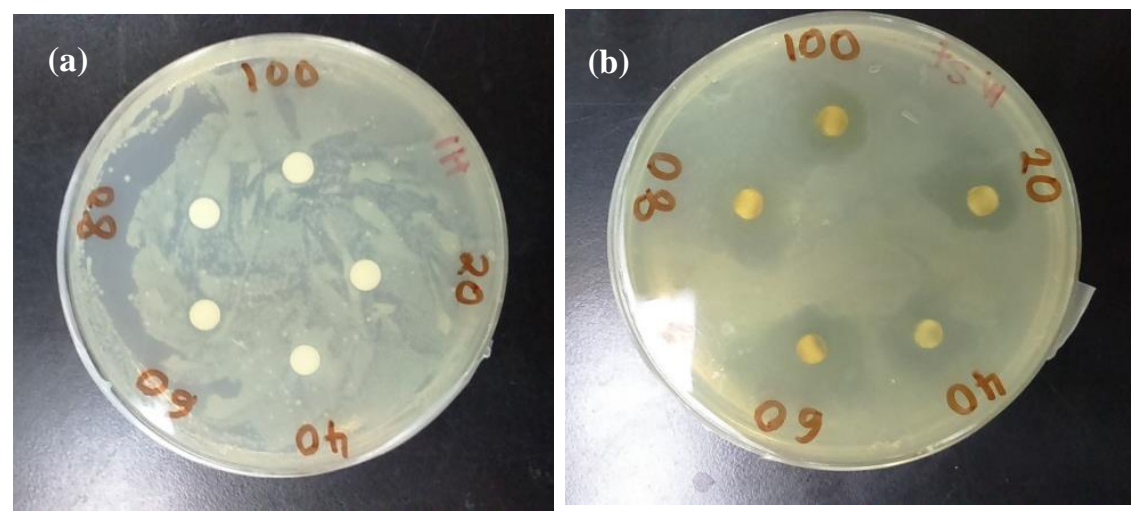

Figure 1. Disc-diffusion method of leaves extracts against S. epidermidis: (a) hexane extract and (b) methanol extract

Table 3 shows antimicrobial activities of hexane and methanol against T. mentagrophytes. For T. mentagrophytes, the best concentration were $40 \mathrm{mg} / \mathrm{ml}$ extract and $60 \mathrm{mg} / \mathrm{ml}$ extract, which showed the same diameter of inhibition zone of $5 \mathrm{~mm}$ (Figure 2). Nystatin, which was used as the positive control to act against the T. mentagrophytes, showed weak effects on the fungal colonies by forming $2 \mathrm{~mm}$ clear zone. This might be due to the inadequate dosage against the number of colonies. The observed antibacterial effects on the isolates are believed to exist, due to the presence of tannins, alkaloids and flavonoids which have been shown to possess antibacterial properties [11, 12].

Table 3. Antimicrobial activities of hexane and methanol extracts against T. mentagrophytes

\begin{tabular}{lcc}
\hline \multirow{2}{*}{$\begin{array}{l}\text { Concentration } \\
(\mathbf{m g} / \mathbf{m l})\end{array}$} & \multicolumn{2}{c}{ Average Inhibition Zone $(\mathbf{m m})$} \\
\cline { 2 - 3 } & Hexane Extract & Methanol Extract \\
\hline 20 & - & $2.0 \pm 0.58$ \\
40 & - & $5.0 \pm 0.33$ \\
60 & - & $5.0 \pm 0.33$ \\
80 & - & $4.0 \pm 0.33$ \\
100 & - & $3.0 \pm 0.24$ \\
Nystatin & $2.0 \pm 0.58$ & $2.0 \pm 0.58$ \\
\hline
\end{tabular}

Data given are mean \pm standard deviation
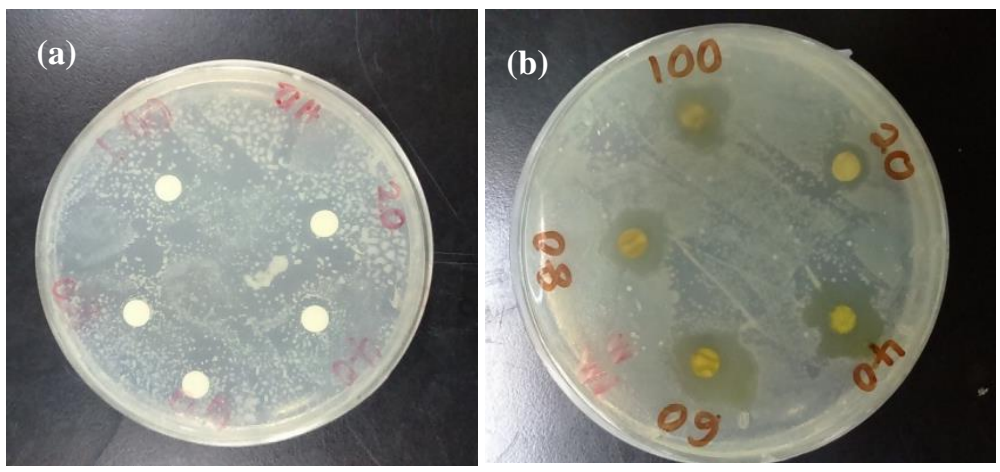

Figure 2. Disc-diffusion method of leaves extracts against T. mentagrophytes: (a) hexane extract and (b) methanol extract 
Figure 3 shows the effect of methanol extract against different microorganisms S. epidermidis and T. mentagrophytes. For T. mentagrophytes, the inhibition zone showed decreasing trend as the concentration exceeded $60 \mathrm{mg} / \mathrm{ml}$. According to Ibrahim and Osman [13], increasing the concentrations of the extracts gave the results of decreasing of the growth of dermatophytes. Based on the graph, the methanolic extract showed the best results against $T$. mentagrophytes at the concentration of $40 \mathrm{mg} / \mathrm{ml}$ whereas $60 \mathrm{mg} / \mathrm{ml}$ was needed to give the best size of inhibition zone for $S$. epidermidis. The result illustrated the possibility of banana leaves extract to become as potential drug based on its antifungal properties.

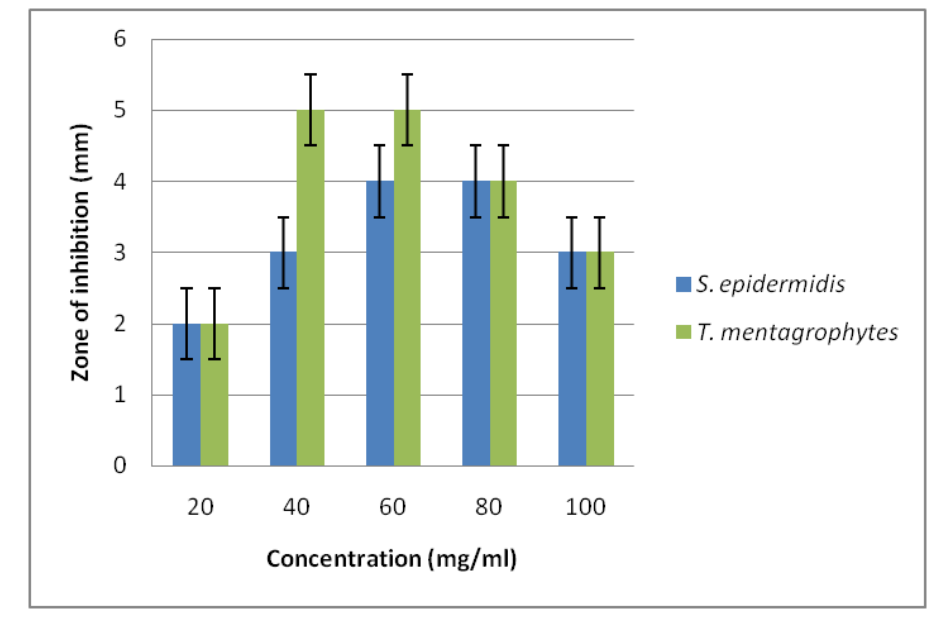

Figure 3. Effects of methanol extract against tested microorganisms

\section{Conclusion}

In the present study, the banana leaves were used to identify the phytochemical and antimicrobial properties. Among all the phytochemical constituents tested, only alkaloids were detected in hexane extract and all of the chemicals presents in methanol extract. For the antimicrobial activities, only methanol extract of M. acuminata 'Dwarf Cavendish' gave effects to both microorganisms tested. The results of the study have proven that the leaves of the banana contain medicinal properties, and thus can potentially be used in the antibacterial formulation in pharmaceutical industries such as in production of cream or other health care products.

\section{References}

1. Cowan, M. M. (1999). Plant products as antimicrobial agents. American Society for Microbiology, 12(4): 564582.

2. Arif, T., Bhosale, J. D., Kumar, N., Mandal, T. K., Bendre, R. S., Lavekar, G. S. and Dabur, R. (2009). Natural products-antifungal agents derived from plants. Journal of Asian Natural Products Research, 11(7): 621-638.

3. Oliveira, L., Cordeiro, N., Evtuguin, D. V., Torres, I. C. and Silvestre, A. J. D. (2007). Chemical composition of different morphological parts from 'Dwarf cavendish' banana plant and their potential as a non-wood renewable source of natural products. Industrial Crops and Products, 26(2):163-172.

4. Evans, E. and Ballen, F. (2012). Banana market (FE901). UF Department of Food and Resource Economics: pp. $1-9$.

5. Kumar, P. R., Srivastava, S., Singh, K. K., Mathad, C. and Thind, P. S. (2014). Study of antioxidant and antimicrobial properties, phytochemical screening and analysis of sap extracted from banana (Musa acuminata) pseudostem. International Journal of Advanced Biotechnology and Research, 5(4): 649-658.

6. Cruz-Cruz, C. A., Ramírez-Tec, G., García-Sosa, K., Escalante-Erosa, F., Hill, L., Osbourn, A. E. and PeñaRodríguez, L. M. (2009). Phytoanticipins from banana (Musa acuminata Cv. Grande Naine) plants, with antifungal activity against Mycosphaerella fijiensis, the causal agent of black sigatoka. European Journal of Plant Pathology, 126(4): 459-463. 
Siti Suhaila et al: PHYTOCHEMICAL SCREENING, ANTIFUNGAL AND ANTIBACTERIAL ACTIVITIES OF Musa acuminata PLANT

7. Kapadia, S., Pudakalkatti, P. and Shivanaikar, S. (2015). Detection of antimicrobial activity of banana peel (Musa paradisiaca L.) on Porphyromonas gingivalis and Aggregatibacter actinomycetemcomitans: An in vitro study (Health and Medicine Complete (Alumni Edition) ed. Vol. 6): Medknow Publications \& Media Pvt. Ltd.

8. Narendra, K., Sowjanya, K. M., Swathi, J. and Satya, A. K. (2012). Phytochemical evaluation \& antimicrobial efficiency of threatened medicinal plant of Andhra Pradesh Pterospermum xylocarpum (Thada Tree). International Research Journal of Pharmacy, 4(2): 155-160.

9. Tiwari, P., Kumar, B., Kaur, M., Kaur, G. and Kaur, H. (2011). Phytochemical screening and extraction - a review. Internationale Pharmaceutical Sciencia, 1(1): 98-104.

10. Shittu, G. A. and Akor, E. S. (2015). Phytochemical screening and antimicrobial activities of the leaf extract of Entandrophragama angolense. African Journal of Biotechnology, 14(3), 202-205.

11. Awoyinka, O. A., Balogun, I. O. and Ogunnowo, A. A. (2007). Phytochemical screening and in vitro bioactivity of Cnidoscolus aconitifolius. Journal of Medicinal Plants Research, 1(3): 63-65.

12. Thenmozhi, M. and Sivaraj, R. (2010). Phytochemical analysis and antimicrobial activity of Polyalthia longifolia. International Journal of Pharma and Bio Sciences, 1(3): 1-7.

13. Ibrahim, D., \& Osman, H. (1995). Antimicrobial activity of Cassia alata from Malaysia. Journal of Ethnopharmacology, 45(3): 151-156. 